\title{
СОЦІААЬНІ КОМУНІКАЦІЇ
}

DOI: https://doi.org/10.32839/2304-5809/2019-10-74-119

УДК [316.774:004.738.52-027.236+378.4(477.73)]:303.1

Київський національний університет

\section{ПОРІВНЯЛЬНИЙ АНАЛІЗ ЕФЕКТИВНОСТІ ВЕБ-САЙТІВ ДЕРЖАВНИХ ТА КОМЕРЦЙНИХ ЗВО СФЕРИ КУЛЬТУРИ УКРАЇНИ}

\begin{abstract}
Анотація. Виявлено, що найбільш продуктивною та ефективною рекламою ЗВО стають веб-сайти та загальне використання інтернету для комунікацій із цільовими аудиторіями. Проаналізовано ефективність інтернет-представництв у питанні інформування студентів і створення та підтримки іміджу ЗВО сфери культури України. Відзначено різницю між державними і комерційними закладами освіти. Для оцінки ефективності веб-сайтів закладів вищої освіти сфери культури було здійснено їх контент-аналіз. На основі контент-аналізу виявлено, які сайти ЗВО сфери культури України є найбільш комунікативно-ефективними, що свідчить про зацікавленість даних закладів вищої освіти у тому, щоб власний ЗВО впізнавали та віддавали йому перевагу, про бажання університетів мати сприятливий імідж та залучати широку аудиторію для комунікації.
\end{abstract}

Ключові слова: державні та комерційні ЗВО, ефективність веб-сайтів, ЗВО сфери культури.

Zatserkivna Marina Kyiv National University of Culture and Arts

\section{COMPARATIVE ANALYSIS OF THE EFFICIENCY OF WEBSITES OF STATE AND COMMERCIAL UNIVERSITIES OF CULTURE OF UKRAINE}

Summary. The aim of the article is to analyze the current websites of state and commercial universities of culture of Ukraine for the efficiency of their use. Methodology. In order to effectively achieve the goal of the research, an analytical method was used to analyze the websites of state and commercial universities of Ukrainian culture for their effectiveness. Results. Internet communication today is one of the promising ways of positioning a higher education institution as a training and scientific center. That is why the university public relations department should make every effort to make its website user-friendly and easy to use, since the sites reveal the maximum number of directions of the institution's activity on their pages and provide visitors with a number of additional services, which greatly facilitates the work of users with available information resources. Based on the results of the research, it can be stated that all higher education institutions represented in the research have developed their own websites. This demonstrates the interest of Ukrainian cultural universities in recognizing and giving preference to their own university, the desire of universities to have a favorable image and attract a wide audience for communication. Prospective direction of continuation of the research is the issue of PR-technologies as the main tool of formation and management of image of institutions of higher education of the cultural sphere, detailed consideration of functions, structure and bases of formation of image of educational institution and PR-support of management of image of institutions of higher education of culture. Scientific novelty. The effectiveness and expediency of the websites of state and commercial universities of culture of Ukraine were investigated. Practical meaning. The results of the article are of practical importance in the study of social relations as a type of activity and managerial functions. The provisions formulated in the document can be used to develop courses on scientific disciplines "Public Relations", "Image Making", as well as for further writing articles on the peculiarities of the use of PR-technologies in shaping the image of higher education institutions.

Keywords: state and commercial universities, website performance, cultural universities.

$\Pi^{2}$ остановка проблеми. На сьогодні можна констатувати той фракт, що традиційні ЗМІ поступаються цифровим та інтерактивним, які дають можливість не тільки пасивно споживати інформацію, а й брати активну участь у їі формуванні та обміні. Ми можемо спостерігати, як з'являеться «інформаційна демократія», аудиторія «кліками» голосує за той чи інший контент, при цьому перетворюючи автора у «зірку» нових медіа. Тому перед ЗВО виникає проблема донести ці тренди до цільової аудиторії, сформувати компетенщіі, які дають змогу орієнтуватися в новому медіа-середовищі.

Найбільш продуктивною та ефективною рекламою ЗВО стають веб-сайти та загальне використання інтернету для комунікацій із цільовими аудиторіями. Використання мережі інтернет - це можливість побудувати стійкі і довгострокові зв'язки 3 цільовими аудиторіями та надання їм можливості отримати найбільш точну та цікаву інформацію про ЗВО.

Аналіз останніх досліджень і публікацій. Розповсюдженість використання інтернету в різних сдерах життедіяльності суспільства, включаючи сферу освіти - одна із найактуальніших для дослідження тем. Так, різні аспекти використання можливостей інтернет-комунікації навчальними закладами для потреб власної популяризації, інформування громадськості, рекламування освітніх послуг, піднесення іміджу та виходу на нові цільові групи порушували у свої дослідженнях такі автори, як А.Б. Зверінцев [5], В.Г. Королько [7], В.М. Маренич [8], Т.С. Оболенська [9], О.М. Холод [10] та інші. Водночас наукових 
праць, присвячених структурному аналізу вебсайтів як засобів комунікації освітніх закладів із цільовими групами громадськості, все ще бракуе.

Виділення невирішених раніше частин загальної проблеми. Поширені в науковому та діловому світі підходи не відповідають на цілий ряд запитань, пов'язаних 3 едективністю використання інтернету в створенні та підтримці іміджу ЗВО. Зокрема потребує уваги контент аналіз веб-сайтів державних та комерційних ЗВО культури України.

Мета статті - аналіз чинних веб-сайтів державних та комерційних 3 ВО культури України на предмет ефективності їх використання.

Виклад основного матеріалу дослідження. Інтернет-присутність у питанні індрормування студентів і створення та підтримки іміджу ЗВО є одним з перспективних шляхів реалізації позиціонування 3ВО. Більшість абітуріентів мають навички роботи 3 новими технологіями, i сайт - найперше джерело, яке допомагає отримати інформацію про ЗВО. Ефективність інтернет-представництва, по-перше, полягає в тому, що використовувані в роботі сайту елементи (тривимірна графіка, хороша навігація, гіперпосилання) дають змогу створити відчуття близької реальності, залишають у свідомості об'ємні, реальні образи. По-друге, сайт слугуе інформаційним ресурсом; по-трете, це ще один спосіб сдрормувати позитивне ставлення до 3ВО, переконати цільову аудиторію в надійності, стабільності, інноваційності та інших характеристиках 3ВО [4].

Наразі більшість закладів освіти мають свої інтернет-представництва. Сайти виконують безліч фонкцій, таких як інформащійна, збір думок і оцінок, розважальна, гносеологічна, культурологічна, соціальна та інші. Безперечно, що завдяки виходу в інтернет громадськість має можливість своєчасно і легко отримати необхідну інформащію, але варто відзначити, що не завжди досягаеться мета, яка ставилася при розробці сайту, - створення цілісного візуального образу, що дає змогу сформувати позитивне ставлення до ЗВО. Якщо розглядати сайт лише як данину моді чи сучасності, то едективність подібного сайту дуже мала. Сайт ЗВО - канал комунікаціï, який повинен виправдовувати своє існування. Сайт з позищії PR-діяльності розглядаеться як набір інформащійних блоків та інструментів для взаємодії з цільовими сегментами аудиторії: абітурієнтами, студентами, аспірантами, викладачами [6, с. 16-17]. Звідси можна зробити висновок, що будь-який сайт - це структура, що складається зі змісту, тобто інформації, та форми її подання, тобто дизайну. Як справедливо зазначає I. Альошина, сайт повинен швидко заволодівати увагою відвідувача, тому що конкуренти за увагу перебувають на відстані всього лише клацання миші [1].

Варто відзначити різницю між державними i комерційними закладами освіти. Державний заклад освіти - це заклад освіти, засновниками якого є уряд або органи виконавчої влади, фрінансування здійснюється державою з коштів державного або муніципального бюджету. Комерційний заклад освіти - освітній заклад, заснований комерційними організаціями, суспільними організаціями або приватними особами. Джерелами фрі- нансування комерційного ЗВО служать бюджети цих організацій і плата за навчання.

Хоча державні 3ВО мають довшу історію і свої традиції, комерційні ЗВО стають все популярнішими, насамперед, завдяки інноваційному підходу. Тут частіше застосовуються авторські програми, постійно вдосконалюеться матеріально-технічна база, до того ж багато недержавних ЗВО надають студентам можливість пройти стажування за кордоном, часто використовують більше «зовнішніх» викладачів-практиків [3].

Для подальшого аналізу сайтів 3ВО сфери культури України вважаємо за необхідне перерахувати щі ЗВО.

Державні ЗВО сфери культури України: Київський національний університет культури i мистецтв; Київський національний університет театру, кіно і телебачення імені I.К. КарпенкаКарого; Луганська державна академія культури і мистецтв; Львівська національна музична академія імені М.В. Лисенка; Національна академія образотворчого мистецтва і архітектури; Національна академія керівних кадрів культури і мистецтв; Національна музична академія України імені П.І. Чайковського; Одеська національна музична академія імені А.В. Нежданової; Харківська державна академія культури; Харківський національний університет мистецтв імені І.П. Котляревського.

Комерційні ЗВО сорери культури України: Дніпропетровська консерваторія імені М. Глінки; Київська дитяча академія мистецтв; Київська муніципальна академія естрадного та циркового мистецтв; Київський університет культури.

Аналізуючи сайти ЗВО сфрери культури України, можна зробити висновки:

1) Комерційні ЗВО, порівняно з державними, використовують більш цікаві прийоми і ефректи в побудові інформащії на сайті та у розробці дизайну (наприклад ПВНЗ Київський університет культури (http://kuk-university.com/) або Дніпропетровська академія музики ім. М. Глінки (http://dk.dp.ua/)). Можливо, це пов'язано 3 бажанням комерційних 3 ВО довести, що їхні освітні послуги не поступаються державним. За рахунок реклами, інтернет-представництва, PRакцій комерційні 3ВО прагнуть залучити абітурієнтів. Для більшості державних ЗВО інтернет-представництво не має особливого значення, 3ВО не намагаються привернути до себе увагу, їм не потрібно себе якимось чином позиціонувати, ЗВО - державний, а значить існує давно i вже сорормував певну репутацію за роки свого існування (наприклад Київський національний університет театру, кіно і телебачення ім. I. Карпенка-Карого (http://knutkt.com.ua/)). Використання інтернет-технологій - ще один показник інноваційності.

2) Комерційні ЗВО за допомогою сайту намагаються максимально висвітлити свою історію. Такий підхід, 3 одного боку свідчить про відкритість ЗВО, 3 іншого боку, показуеться динамічність розвитку i досягнень, напрацьований досвід (наприклад Київська муніципальна академія естрадного та циркового мистецтв (https://circusacademy.kiev.ua/), ПВНЗ Київський університет культури (http://kuk-university.com/) або Дніпропетровська академія музики 
iм. М. Глінки (http://dk.dp.ua/)). Державні 3ВО приділяють увагу своїй історії, але не вказують майбутніх перспектив (наприклад Луганська державна академія культури і мистецтв (https:// ldakm.edu.ua/) та Одеська національна музична академія імені А. Нежданової (http://odma.edu.ua/)).

3) Наука і наукові дослідження, що включають такі вкладки: дослідження, проекти, науково-практичні конференщії, семінари. Цей інформаційний блок дає змогу сформувати характеристики: інноваційність, науковий потенціал, серера застосування та реалізації проектів. Робота студентів і викладачів (на головній сторінщі сайту відсутній блок "Наука" в таких комерційних ЗВО сфери культури - Київська муніципальна академія естрадного та циркового мистецтв (https://circusacademy.kiev.ua/), Київська академія мистецтв (http://www.kdam. kiev.ua/), ПВН3 Київський університет культури (http://kuk-university.com/) та в державному ЗВО - Національна академія образотворчого мистецтва і архітектури (http://naoma.edu.ua/)).

4) Блоки з цільовою спрямованістю: абітурієнтам, студентам, аспірантам. Широкий спектр інформації за цими напрямами: для абітурієнтів вступні випробування, пільги, умови вступу; для студентів - розклад занять (не на всіх сайтах), оглядові лекції з різних дисциплін, інфрормація про конкурси, проекти, можливі варіанти працевлаштування; для аспірантів - екзаменаційні питання, терміни проведення вступних випробувань, добірка літератури для підготовки, рекомендації Вченої ради. Цей блок інформації дає змогу взаємодіяти з різними цільовими групами ЗВО. Вся річ у тому, що ЗВО не схильні фрормувати їхню лояльність і встановлювати гармонійні стосунки, адже щорічно приходять тисячі абітурієнтів (аналіз сайтів ЗВО сфрери культури свідчить, що комерційні та державні ЗВО мають блоки з цільовою спрямованістю).

5) Стрічка новин: новини, події, анонси, оголошення. Цей блок інформації присутній на багатьох сайтах, але оновлюеться не так часто. Проблема оновлення інформації на сайті пов'язана 3 технічною підтримкою сайту і наданою інфрормацією. Важливо, однак, враховувати, що оновлення в новинах показують життя і діяльність ЗВО, формують характеристику динамічності, сучасності, мобільності (рідко оновлюеться стрічка новин на сайті комерційного ЗВО Дніпропетровська академія музики ім. М. Глінки (http://dk.dp.ua/) та державного ЗВО Луганська державна академія культури і мистецтв (https://ldakm.edu.ua/)).

6) Міжнародні зв'язки, партнери. Цей інформащійний блок дає змогу судити про можливості, роботу та перспективи ЗВО. Міжнародні проекти, виставки, конференції, обмін студентами, викладачами (останне дуже часто зустрічається в європейських 3ВО). Це показник можливостей ЗВО для широкого загалу, в тому числі для державних сфрер, бізнесу, місцевої громади (відсутня інформація на сайтах комерційних ЗВО Дніпропетровська академія музики ім. М. Глінки (http://dk.dp.ua/), Київська муніципальна академія естрадного та циркового мистецтв (https://circusacademy.kiev.ua/), Київська академія мистецтв (http://www.kdam.kiev.ua/) та дер- жавного ЗВО - Одеська національна музична академія імені А. Нежданової (http://odma.edu.ua/)).

7) Тематичні форуми, відгуки випускників дають змогу задіяти умови інтерактивності. Сайт це не тільки ресурс, а й платформа для спілкування, обмін думками і поглядами. У гостьову можна запрошувати різних вчених, колишніх випускників, які будуть ділитися своїм думками, відповідати на запитання користувачів (відсутня інформація на сайті комерційного ЗВО Київська Академія мистецтв (http://www.kdam.kiev.ua/)).

8) Електронна бібліотека - корисний блок для студентів, абітурієнтів, аспірантів. Одна 3 головних переваг такої бібліотеки - можливість доступу до електронних версій відразу декількох користувачів (відсутній блок на сайтах комерційних ЗВО Київська муніципальна академія естрадного та циркового мистецтв (https://circusacademy.kiev.ua/), ПВНЗ Київський університет культури (http://kuk-university. com/) та в державних 3BО - Національна академія образотворчого мистецтва і архітектури (http://naoma.edu.ua/), Київський національний університет театру, кіно і телебачення ім. I. Карпенка-Карого (http://knutkt.com.ua/), Луганська державна академія культури і мистецтв (https://ldakm.edu.ua/)). Особливу увагу необхідно приділити навігації сайту. 3 одного боку, - це полегшує подорож користувача по сайту, -3 іншого $\epsilon$ едрективним способом спрямування користувача на необхідні сторінки. Встановивши статистику відвідувань, можливо вирахувати кількість відвідувачів сайту за день.

9) «Кімната для преси». Сайт ЗВО є одним 3 основних джерел інформації для журналістів, які працюють на онлайнові видання або на традиційні ЗМI. Тому дуже логічно у структуру сайту включити інформаційний блок для журналістів, де можливе розміщення прес-релізів, коментарів щодо тенденцій в освіті тощо. У зарубіжних компаніях подібні сторінки звуться "press room» або «news room». Таким чином формується бажаний інфрормаційний простір, журналісти публікують інформацію на основі відомостей з сайту і завжди можуть зробити посилання на наданий матеріал. Для інтерактивності необхідно, щоб журналісти могли ставити питання на веб-сторінці (на сайтах 3ВО сфери культури цей блок відсутній).

10) Карта сайту і пошук на сайті: елементи, що дають змогу орієнтуватися у просторі сайту і шукати необхідну інформацію (всі сайти 3ВО сорери культури мають цей блок).

Отже, комунікація - невід'ємна складова освітнього процесу. Як двосторонній процес комунікація обумовлюе безпосередній і миттевий зворотній зв'язок між виробником і споживачем освітньої послуги, створює основу для взаємодії між ними [2].

Для ощінки ефрективності інтернет-сайтів закладів вищої освіти сфери культури було здійснено контент-аналіз. За наявності на веб-сайті кожної одиниці аналізу, ЗВО приписуеться один бал.

Отже, здійснивши аналіз відповідних сайтів ЗВО сорери культури України, можна констатувати, що серед державних 3 ВО найбільш комунікативно-едективними є сайти таких 3ВО: Київський національний університет культури і мистецтв; Львівська національна музична академія імені 
Таблиця 1

Контент-аналіз структурних характеристик веб-сайтів ЗВО культури України

\begin{tabular}{|c|c|c|c|c|c|c|c|c|}
\hline Параметри ЗВО & 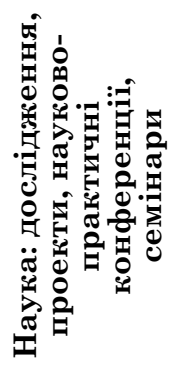 & 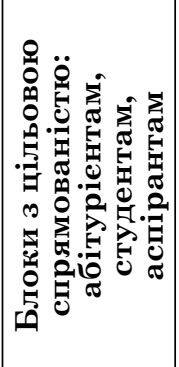 & 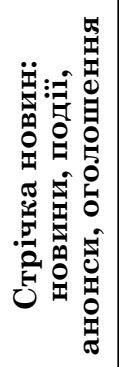 & 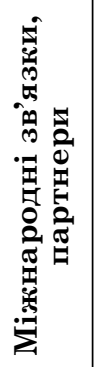 & 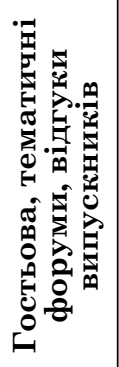 & 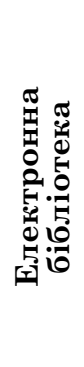 & 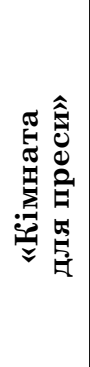 & 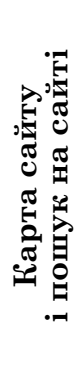 \\
\hline \multicolumn{9}{|c|}{ Державні ЗВО } \\
\hline $\begin{array}{l}\text { 1) Київський національний університет } \\
\text { культури і мистецтв }\end{array}$ & 1 & 1 & 1 & 1 & 1 & 1 & - & 1 \\
\hline $\begin{array}{l}\text { 2) Київський національний університет } \\
\text { театру, кіно і телебачення імені } \\
\text { I.К. Карпенка-Карого }\end{array}$ & 1 & 1 & 1 & 1 & 1 & - & - & 1 \\
\hline $\begin{array}{l}\text { 3) Луганська державна академія культури } \\
\text { i мистецтв }\end{array}$ & 1 & 1 & - & 1 & 1 & - & - & 1 \\
\hline $\begin{array}{l}\text { 4) Львівська національна музична } \\
\text { академія імені М.В. Лисенка }\end{array}$ & 1 & 1 & 1 & 1 & 1 & 1 & - & 1 \\
\hline $\begin{array}{l}\text { 5) Національна академія образотворчого } \\
\text { мистецтва і архітектури }\end{array}$ & - & 1 & 1 & 1 & 1 & - & - & 1 \\
\hline $\begin{array}{l}\text { 6) Національна академія керівних кадрів } \\
\text { культури і мистецтв }\end{array}$ & 1 & 1 & 1 & 1 & 1 & 1 & - & 1 \\
\hline $\begin{array}{l}\text { 7) Національна музична академія України } \\
\text { імені П.І. Чайковського }\end{array}$ & 1 & 1 & 1 & 1 & 1 & 1 & - & 1 \\
\hline $\begin{array}{l}\text { 8) Одеська національна музична академія } \\
\text { імені А.В. Нежданової }\end{array}$ & 1 & 1 & 1 & - & 1 & 1 & - & 1 \\
\hline $\begin{array}{l}\text { 9) Харківська державна академія } \\
\text { культури }\end{array}$ & 1 & 1 & 1 & 1 & 1 & 1 & - & 1 \\
\hline $\begin{array}{l}\text { 10) Харківський національний університет } \\
\text { мистецтв імені І.П. Котляревського }\end{array}$ & 1 & 1 & 1 & 1 & 1 & 1 & - & 1 \\
\hline \multicolumn{9}{|c|}{ Комерційні ЗВО } \\
\hline $\begin{array}{l}\text { 11) Дніпропетровська консерваторія імені } \\
\text { М. Глінки }\end{array}$ & 1 & 1 & - & - & 1 & 1 & - & 1 \\
\hline 12) Київська дитяча академія мистецтв & - & 1 & 1 & - & - & 1 & - & 1 \\
\hline $\begin{array}{l}\text { 13) Київська муніципальна академія } \\
\text { естрадного та циркового мистецтв }\end{array}$ & - & 1 & 1 & - & 1 & - & - & 1 \\
\hline 14) Київський університет культури & - & 1 & 1 & 1 & 1 & - & - & 1 \\
\hline
\end{tabular}

М.В. Лисенка; Національна академія керівних кадрів культури і мистецтв; Національна музична академія України імені П.І. Чайковського; Харківська державна академія культури; Харківський нащіональний університет мистецтв імені І.П. Котляревського. Серед комерційних ЗВО найбільш комунікативно-едективними є сайти таких 3ВО: Дніпропетровська консерваторія імені М. Глінки; Київський університет культури.

В цілому, можна стверджувати, що всі ЗВО серери культури України намагаються «крокувати в ногу» з сучасними інформаційними технологіями, адже сайт кожного з них набрав більше середнього балу за великою кількістю критеріїв.

Висновки 3 даного дослідження. Інтернеткомунікація сьогодні є одним із перспективних шляхів позиціонування закладу вищої освіти як навчально-наукового центру. Саме тому керівництво відділу зв'язків із громадськістю ЗВО має зробити все можливе, щоб його веб-сайт був зручним та зрозумілим у користуванні, адже сайти розкривають на своїх сторінках максимальну кількість напрямів діяльності закладу та надають відвідувачам ряд додаткових сервісів, що істотно полегшуе роботу користувачів із наявними інформаційними ресурсами.

За підсумками здійсненого дослідження, можна стверджувати, що всі представлені у дослідженні заклади вищої освіти мають доволі розвинені власні веб-сайти. Це свідчить про зацікавленість 3ВО сфери культури України у тому, щоб власний 3 ВО впізнавали та віддавали йому перевагу, про бажання університетів мати сприятливий імідж та залучати широку аудиторію для комунікащії.

Перспективним напрямом продовження дослідження $є$ питання PR-технологій як основного інструмента формування та управління іміджем ЗВО сорери культури, детальний розгляд фрункцій, структури та основ формування іміджу освітнього закладу та PR-супроводження управління іміджем ЗВО сфери культури. 


\section{Список літератури:}

1. Алешина И.В. Паблик рилейшнз для менеджеров и маркетеров. Москва : Гном-Пресс, 1997. 336 с.

2. Дагаева Е.А. Маркетинговые коммуникации как способ конструирования имиджа негосударственного вуза. $P R$ в образовании. 2008. № 4. С. 66-70.

3. Даниленко Л.В. Менеджмент имиджа образовательного учреждения. Справочник руководителя образовательного учреждения. 2003. № 1. С. 19-24.

4. Жарська І.О., Зіньковська Д В. Використання інтернет-середовища для просування освітніх послуг вищих навчальних закладів. Вісник Київського національного університету технологій та дизайну. 2015. № $1(83)$. C. $49-58$.

5. Зверинцев А.Б. Коммуникационный менеджмент : рабочая книга менеджера PR. 2-е изд., испр. СанктПетербург : СОЮЗ, 1997. 288 с.

6. Калашнікова Л.В. Інтернет-сайти вищих навчальних закладів як інноваційні канали комунікації в умовах формування інформаційного суспільства в Україні : автореферат дис. на здоб. наук. ступ. канд. соціол. наук : 22.00.04. Харків, 2005. 20 с.

7. Королько В.Г. Основы паблик рилейшнз. Киев : «Ваклер», «Рефл-бук», 2000. 282 с.

8. Маренич B.M. Роль PR-технологій в управлінні формуванням іміджу вищого навчального закладу. Вісник Харківського національного університету внутрішніх справ. 2013. № 2. C. 220-229.

9. Оболенська Т.Є. Маркетинг освітніх послуг: вітчизняний та зарубіжний досвід. Київ : КНЕУ, 2001.208 с.

10. Холод О.М. Комунікаційні технології : підручник. Київ : КиМУ, 2012. 263 с.

\section{References:}

1. Aleshina, I. (1997). Public relations for managers and marketers. Moskva : Gnom-Press. (in Russian)

2. Dagaeva, E. (2008). Marketing communications as a way of constructing the image of a non-state university. $P R$ in education, 4, 66-70. (in Russian)

3. Danylenko, L. (2003). Educational institution image management. Educational institution image management, 1, 19-24. (in Russian)

4. Zharska, I., \& Zinkovska, D. (2015). Use of the Internet environment to promote the educational services of higher education institutions. Bulletin of the Kiev National University of Technology and Design, 1(83), 49-58. (in Ukrainian)

5. Zverincev, A. (1997). Communication Management: Workbook for PR Manager. (2nd ed., Rev). Sankt-Peterburg : SOIUZ. (in Russian)

6. Kalashnikova, L. (2005). Websites of higher education institutions as innovative communication channels in the conditions of formation of information society in Ukraine (The dissertation author's abstract for the candidate's degree in sociology : 22.00.04). Kharkiv National University of Internal Affairs. Kharkiv. (in Ukrainian)

7. Korolko, V. (2000). The basics of public relations. Kyiv : Vakler, Refl-buk. (in Russian)

8. Marenych, V. (2013). The role of PR-technologies in managing the image formation of a higher education institution. Bulletin of the Kharkiv National University of Internal Affairs, 2, 220-229. (in Ukrainian)

9. Obolenska, T. (2001). Marketing of educational services: domestic and foreign experience. Kyiv: KNEU. (in Ukrainian)

10. Holod, O. (2012). Communication technologies : a textbook. Kyiv : KiMU. (in Ukrainian) 